\title{
An Investigation into the Rule of Action in the Penal System
}

\author{
Sahar Zadnahal ${ }^{1} \&$ Iraj Goldozian ${ }^{2}$ \\ ${ }^{1}$ Department of Law, Faculty Law and Political Science, Alborz Science Research Branch Islamic Azad \\ University, Karaj, Iran \\ ${ }^{2}$ Department of Law, Faculty Law and Political Science, Professor of Criminal Justice,University of Tehran, \\ Tehran, Iran \\ Correspondence: Sahar Zadnahal, Department of Law, Faculty Law and Political Science, Alborz Science \\ Research Branch Islamic Azad University, Karaj, Iran. E-mail: Sahar.zadnahal@yahoo.com
}

Received: January 21, 2016 Accepted: February 16, 2016 Online Published: March 31, 2016

doi:10.5539/jpl.v9n2p96 URL: http://dx.doi.org/10.5539/jpl.v9n2p96

\begin{abstract}
According to definite jurisprudential principles and rules, when a person acts against himself and accepts the incurrence of damage, he will be deprived of all or some part of the claim for compensation. The rule of action constitutes the basis of this lack of benefit in Islamic and Iran's law, while the principles of consent and participation in the fault underlie it in the common law. Studying research studies conducted in relation to the rule of action in Iran and Britain's law it could be argued that the rule of action is among the cases discussed in criminal law and on the issue of causality in punishment. On the other hand, in criminal proceedings, in Iranian and British legal systems, this issue has been mostly discussed regarding the aspects of imposing damage and calculation of costs thereof. Therefore, if someone is acting to the detriment of himself and is causing damage to himself, in addition to the issue of liability removal, in which the accused may be acquitted from his responsibility, there is no need for the accused person to pay compensation to the injured person.
\end{abstract}

Keywords: rule of action, civil liability, detrimental accident, fault, participation

\section{Introduction}

Rule of action is one of the jurisprudential rules which although it has not been analyzed independently by the former scholars, but it has been referred in many provisions. According to this principle, anyone who attempts to harm himself and disrespect his wealth, he loses the right to claim compensation. Investigating the rule of action, as a jurisprudential rule is very important, because jurisprudential rules have a very general formula and they are the origin of inference of limited rules and can be considered as the bases of various laws. This knowledge is therefore important that Imam Reza says, "We express the general jurisprudential rules and principles and you must infer the verdicts for minor cases, based on these principles and rules" (Shirazi, 2009, p. 21). It should be said that the term "action" has been used in two senses in jurisprudential sources:

1) Action to Liability

2) Action to Remove the Liability

Here the rule of action refers to action to remove the liability. Jurisprudents have often discussed this principle in the issue of removing liability and that detrimental action is more important than disrespecting his property and in this case nobody will be responsible to pay the compensation; because the origin of liability is respecting the property, which the owner has ruined it. It is like a case in which the buyer buys an object with the knowledge of its defects or when he attempts to cancel the transaction after that.

Finally, in explaining the rule of action it should be said that the injured person might be guilty of sloppy behavior. This behavior may be caused by non-compliance with safety matters or may be the result of other issues. Something that is important in this regard is sloppy behavior by injured person and after realization of other conditions it will result in exoneration of the accused person or sharing in compensation; because he is obliged to consider usual care measures for himself and in the event of non-compliance with these measures, he has indeed committed a fault.

An injured person will be deprived of all or some part of the compensation, if he acts against himself knowingly and intentionally. This point can be inferred from the definition of the rule of action and its clear examples and 
from its causes and documentation. In addition, the exempting effect of rule of action depends on existence of knowledge and intention; because this is the intention of injured person, who consents to incur the damage. For example, if someone throws his rubbish out of his house and a passerby intentionally put his foot on it, fell on the ground, and hurt his back; then the property owner is not responsible for the damage, because the injured person has acted to his detriment. Therefore, if the victim acts against himself unknowingly, because of his lack of knowledge the responsibility remains on the person who has caused the damage, because in fact, knowledge and intention, which are the pillars of rule of action, have been eliminated. For example, when someone put poison in another body's food and lies to him and says: I have poured poison into your food, but the poison is not deadly and it is useful for your disease, if that person eats it and then dies, the killer will be sentenced to death; because although the victim has eaten the food, but this action has been the result of factors, which are caused by the killer. Now this question arises that whether the victim should have damaged himself intentionally, is the damage predictable for him? If he does not want to harm himself, does the exempting effect of rule of action remain effective? Are general and specific issues effective in rule of action as they affect the realization of criminal act in criminal actions?

Some legal experts differentiate between consent of injured person and his knowledge of possibility of damage and they believe that "knowledge, without acceptance, is not considered as guilt". Therefore, if someone takes the train or car, already knowing that some accident may happen in the journey, and does not pay attention to this issue, such intention will not be considered as a fault to reduce the liability of defendant (the driver). However, when someone attends a dangerous sport (such as boxing or karate) in which he is subjected to be injured by his opponent, if his opponent does injure him, then such an action is not the fault of the opponent, unless the cause of the accident is violation of regulations related to the sport.

\section{Investigating the rule of action in the penal system}

\section{Research Purposes}

1) Investigating the status of rule of action in the penal system

2) Investigating the rule of action as a fundamental principle of exemption of criminal responsibility

3) Investigating characteristics of penal system regarding rule of action

In this study, a descriptive and analytical method was used; in that at the first step, it was attempted to identify and describe the rule of action and then the issue was analyzed. The study was conducted based on a common research method, in a scientific community, like most studies in the field of humanities. The data collection method was based on library research. The materials were mainly obtained from internal and external sources, including books, articles, documents, and international treaties, through using the Internet. Afterwards, the data were analyzed as follows:

After collecting the materials using library methods and studying sources through note taking, first, various opinions regarding raised issues were discussed and then their arguments in the legal system were evaluated. Then the primary and secondary research questions were answered, in accordance with rational and logical methods and finally conclusions were made and disadvantages and shortcomings of governing regulations were enumerated. In the end, suggestions were provided in order to improve the status quo and amend the law.

\section{Definition of Rule of Action}

Action literally means going ahead in a work, starting something and coming along (Dehkhoda, 1998, p. 3117). In Islamic jurisprudence, certain actions and sayings, which cause physical or financial commitment, are known as liability tools, and the financial and physical commitment, in general is called guarantee. A commitment that is the provision of a liability is a legal relationship between two people, whereby one of them has the right to force the other to pay money, or perform an action or quit it. In contrast to these causes of guarantee, some actions and sayings are considered to eliminate the liability and the rule of action represents one of these cases (Amid Zanjani, 2007, p. 91).

Some of the jurists have defined the 'action' from two jurisprudential and legal (criminal and civil) aspects. Its jurisprudential definition was mentioned above. However, in respect of its legal definition, it must be argued that it is the goodwill and intellectual status in which a person commits an action and thinks that he is acting in accordance with the law, while his action is not in accordance with the law and the legislator will support him to some extent, against the harmful consequences of his action (Safaei, 2004, p. 515). For example, someone may think that he is dealing with a real owner of a property and he may buy the property, while the person has usurped the property and he has not been the owner (Article 1141.549, 2265 French civil law and Article 304 (3) of Iranian Civil Law) or someone may build a building on the land of some other body and may think that that is 
his property. For this reason, Iranian legislator has obliged Iran's Civil Law to implement liability from Article 301 onward, while these Articles were not necessary, because Article 308 of Iran's civil law was enough in this regard (Jafari Langeroudi, 2005, p. 678).

\section{Axes of the Rule of Action}

\section{- Harmful Action (By Victim)}

According to basic principles and rules of civil liability, when the injured person's fault is one of the factors causing the harm, then he will not be able to claim total compensation (Tajmiri, 1996, p. 86). Therefore, this principle will be referable when the injured person acts against his interests. But what action by injured person is considered to be against him? It is obvious that any behavior is not considered to be harmful, but here acting against oneself (except for cases in which the leading motivation is benevolence, such as donations to the poor people) refers to that behavior which has caused the injury.

\section{- Causal Relationship between the Harmful Action and Crime Occurrence}

Mere negligence of injured person is not enough to remove the guarantee, but there must be a causal relationship between the harm and the action. That means the harm must be the result of that action. For example, a person enters into some house and pours poison in animal's feed to kill the dog, now if the landlord eats the food and dies, nobody will be liable in this case (Khomeini, 1425, p. 461). But it should be noted that reason differs from cause and cause is something that if it did not exist, the loss would not had happened; while in some cases a harmful cause may be present, but yet no harm or loss may happen (Ardabili, 2006, p. 253; Gorji, 2001, p. 99). For example, someone may excessively irrigate his own farm and this might moist neighbor' wall, spoil, and damage his wheat. Now if the owner of wheat notices the moisture from the beginning and does not prevent the spread of moisture, his negligence is clear and nobody will be responsible to pay the compensation; because the injured person's negligence has caused the loss and as a result, the first person has not caused the loss. As a result, that person is not responsible to pay the compensation (Jafari Langeroudi, 1379, pp. 1056 and 1057).

\section{- Knowledge and Intention}

Certainly, an injured person will be deprived of all or some part of the compensation, if he acts against himself knowingly and intentionally. This point can be inferred from the definition of the rule of action and its clear examples and from its causes and documentation. In addition, the exempting effect of rule of action depends on existence of knowledge and intention; because this is the intention of injured person, who consents to incur the damage. For example, if someone throws his rubbish out of his house and a passerby intentionally put his foot on it, fell on the ground, and hurt his back; then the property owner is not responsible for the damage (Khomeini, 1425 , p. 510), because the injured person has acted to his detriment. Therefore, if the victim acts against himself unknowingly, because of his lack of knowledge the responsibility remains on the person who has caused the damage, because in fact, knowledge and intention, which are the pillars of rule of action, have been eliminated. For example, when someone put poison in another body's food and lies to him and says: I have poured poison into your food, but the poison is not deadly and it is useful for your disease, if that person eats it and then dies, the killer will be sentenced to death (Khomeini, 1425, p. 510); because although the victim has eaten the food, but this action has been the result of factors, which are caused by the killer.

Now this question arises that whether the victim should have damaged himself intentionally, is the damage predictable for him. If he does not want to harm himself, does the exempting effect of rule of action remain effective? Are general and specific issues effective in rule of action as they affect the realization of criminal act in criminal actions? Obviously, intention has a specific meaning in law. However, the distinction between private and criminal law creates some differences in this regard. It means that in private law, intention to perform an action and performing it is enough to be considered illegal, while in criminal crimes, in some cases, existence of ill will is essential; however, in rule of action, realization of a specific intention is not necessary and mere action to one's own detriment is considered to be sufficient. For example, if a person suddenly runs into a highway and a car hits him, he cannot claim that I was in a hurry and I had not the intention to cause the accidents and damage myself or if a person buys an object with the knowledge of its defects, he cannot claim that I thought that I can claim compensation in case of occurring a damage.

\section{The Burden of Proving the Fault}

\section{- Principle of Participation in the Fault}

In the Middle Ages, when a person was involved in the occurrence of an adverse accident because of negligence in taking care of himself, the court did not determine any compensation, even if the fault of the accused person was far more than that of the injured person (Weir, 2006, p. 123), since according to the prevailing opinion of the 
time, insured's fault cuts the causal relationship between the fault and the damage (Baker, 1993, p. 110). In addition, some of the jurists of that period justified this issue in this way that common sense and the public interest obliges us to base anybody's special interests on his caution and care to force people to behave appropriately in order to protect their own interests (Ferdinand, 19971, pp. 207- 211).

Based on this thought, the theory of Pamponis 'a Roman judge' arose in Roman law. According to this theory, a person acts against himself and incurs damage; he will be deprived of all or some part of the compensation; except for cases in which the fault has been intentional, since Pamponis believed that a loss or damage caused by negligence is not considered as a loss or damage. This theory prevailed in the legal systems of the most European countries and in the United Kingdom this theory was strengthened with supporting an ancient desire which justified all the events by presenting one cause (Fleming, 1985, p. 134).

Among the proposed theories, the theory of punishment and causality was more prevalent in United Kingdom's law (Wayne Field, 1950, p. 240); however, punishing the injured person may not be much reasonable in this regard.

\section{- Theory of Participation in the Fault}

As the issue of a person who acts against himself has been generally considered a tort, the term "Contributory Negligence", which in fact refers to a mutual fault has been prevalent in the common law books in earlier years (Radan Jebeli, 1993, p. 145).

In all cases if the injured person committed negligence, -except for cases of intentional faults- the principle of participation in the fault could be referred to and the accused will be exonerated from paying for compensation (Cook, 1997, p. 131). Therefore, if the court noticed that the injured person has been negligent in his injuries and damages, he was deprived of compensation; because participation in the fault was considered as a full defense. In the case of Battlefield, with the judgment of Forrester, in 1809, the plaintiff who was galloping his horse when suddenly it hit a beam that the accused had negligently left it in the road. It was believed that if the plaintiff could be more careful, no accident would have occurred; therefore, plaintiff's action in this accident is considered to be contributing in the fault and he will be deprived from compensation (Cook, 1997, p. 131).

\section{- The Last Chance Theory}

These problems on one hand and unfair exclusion of negligent injured person from receiving all the compensation on the other hand obliged British courts to decrease the jurisdiction of this legal doctrine (principle of participation in the fault). They conducted several tests in different conditions to investigate this issue and the most famous of which was the last chance theory or the last real chance (Street, 1972, p. 158). According to this theory which required the most accurate studies, that person who had an opportunity to prevent the realization of damage is guilty and the must pay for the compensation, since he has had the last chance to avoid the accident (Williams, 1964, p. 321). The case of Dioiz with the judgment of Mann, in 1824 AD, is good example of this theory. In this case, the plaintiff negligently left his donkey in a road and blocked it and then the accused that was driving a wagon very fast hit the animal and killed it. It was not clear that whether the accused has seen the animal or not? Whether the plaintiff despite his negligence has been enough careful to prevent the accident at the time of seeing the animal or not? The plaintiff was successful in this case, because the accused person could easily prevent the consequences of plaintiff's careless act (Baker, 1993, p. 110). Later, the House of Lords in a car accident in which the driver (accused) was able to prevent accident ignored the old standard of "Contributory Negligence" and announced: "It is important to determine which fault has basically caused the damage" (Street, 1972, p. 292). Finally, the appeal committee also followed this opinion (Street, 1972, p. 154).

\section{Conclusion}

Finally, the following items were concluded through studying the issue:

1) The rule of action is an issue in which liability and its removal have been mentioned, in other words, these two cases are being explained in this principle.

2) Rule of action is being discussed in criminal law on the issue of causality, because the causal relationship justifies action against oneself and specifies its pillars.

3) Fault or negligence in occurrence of damage is an example of acting against oneself, in which the person has damaged himself.

4) The injured person may cause the damage or he may be involved in damaging himself. 
5) Rule of action is connected with other principles in the common law system and the most important of them is principle of participation in the fault. According to this principle, in the common law, no one who damages himself can claim for compensation from someone else.

6) Legitimacy of rule of action has been verified in the holy Quran, in Sunnah and in the Ejmaa (consensus); therefore it could be utilized it in the legislation.

7) Among the most important Jurisprudential principles, which are associated with this principle and can justify this principle, the followings could be mentioned: principles of respect, pride, exoneration, disclaim, removal, deterrence, coercion and saving the life or property of another person.

\section{Recommendations}

The rule of action is a basic and undeniable law, in the penal system. However, there is no formulation or legislation in the legal texts related to this discipline. In other words, a lack of legislation could be observed in this regard.

In explaining and understanding the rule of action foreign sources should be considered; because in English law, many descriptions and inventions have been presented regarding this principle, but in Iran's law and jurisprudence less regulations and rules have been adopted in this respect.

\section{References}

Adl, M. (1963). Civil Law. Amir Kabir Publications.

Ahmadi Vastany, A. (1973). Urgency. Academic Critical Journal of Bar Association, 25(124).

Albojnourdi, M. H. (1424). Jurisprudential rules. Islamic Press Institutions.

Ali Abadi, A. (2006). Criminal law. Ferdowsi Publications.

Amid Zanjani, A. A. (2003). Introduction to civil liability and its tools in Islamic jurisprudence. Tehran: Mizan Publications.

Amid Zanjani, A. A. (2007). The rules of jurisprudence. SAMT publications.

Amid, H. (2005). Persian Dictionary of Amid. Amir Kabir Publications. Mydznjany.

Amini Khiabani, A. (1976). The concept of fault and its role in civil liability. Master's thesis of Private Law, Faculty of Law and Political Sciences, Tehran University.

Amiri Ghaem Magham, A. (1999). The law of obligations. Tehran, Tehran University Press.

Ansari, M. (1410). Almkasib. Darolmktabah, Beirut.

Ansari, S. M. (1433). Makasib. Qom: Lithography, Institute of Islamic Press.

Ardabili, M. A. (2006). General criminal law. Tehran: Mizan Publications.

Bahrami, K. (2002). The rule of causality. Journal of the hearing, 6(31).

Baker, C. D. (1972). Tort of Law. Sweet \& Maxwell co, London.

Bojnordi Mousavi, M. (1998). The concept of the rule of action. Dedication of Immortal Heritage Journal, 23-24.

Bojnordi, M. H. (1992). Jurisprudential rules. Qom: Islamic Publishing Institute.

Cook, J. (1976). Law of tort (4th ed.). Financial times publishing co.

Dehkhoda, A. A. (1998). Dictionary of Dehkhoda. SAMT publications.

Dehkhoda, A. A. (1998). Dictionary of Dehkhoda. Tehran University Publications.

Doroudian, H. (2005). Pamphlet of civil liability. Tehran University.

Emami, S. H. (1975). Disclaimer. Journal of Faculty of Law - "Civil Liability", National University of Shahid Beheshti, 4.

Emami, S. H. (1997). Civil Rights. Islamiyah Publications.

Esfahani, S. M. H. (1418). Makasib Margin. Qom: Elmiah Press.

Ferdinand, F. S. (1971). The basic institutions of the United States of America. Hussain Safai Trans., Pocket Books Publishing Company.

Fleming, J. G. (1985). An Introduction to the law of tort. Lomdon, Clamdon press oxford.

Ghamami, M. (2004). The predictability of loss on civil liability. Tehran: Corporate Publishing. 
Gorji, A. (2001). Blood money. Tehran: Tehran University Press.

Hajizadeh, H. R. (2006). The rule of warning and its role in eliminating criminal liability, Khatte Sevvom Publications.

Harry, S. (1972). the law of tort (5th ed.). London, Butter worth.

Heuston, R. F., \& Chambers, R. S. (1981). Salmond on law of torts (18th ed.). London, Sweet \& Maxwell.

Hoseini Almraghy, M. A. (1425). Jurisprudential Rules. Islamic Press.

Jafari Langroodi, M. J. (1996). Encyclopedia of civil rights and trade. Tehran: Rasta Foundation.

Jafari Langroodi, M. J. (1999). Discussion of Lawterminology. Tehran: Ganje Danesh.

Jafari Langroodi, M. J. (2005). Terminology of Law. Ganje Denesh Publications.

Jafarpoor, J. (2009). The urgency of the Iranian criminal law with regard to the views of Imam Khomeini. Matin Journal.

Joneidi, L. (1999). Interpretation of victim. Journal of Law and Political Science, (46).

Katouzian, N. (1993). Civil Law: out of contract obligations, compulsory guarantee. Tehran: The Institute of Tehran University Press.

Katouzian, N. (1993). Compulsory guarantee. SAMT publications.

Katouzian, N. (2004). Civil Law. Mizan Publications.

Kazemi, M. (1998). The work of victim satisfaction in the civil liability. Master's thesis of Private Law, Faculty of Law and Political Sciences, Tehran University.

Khomeini, R. (2009). Vending. Institute for Preservation of Imam Khomeini's Works.

Khorasani, M. K. (1406). A margin on Makasib. Tehran: Ministry of Islamic Guidance Press.

Khoyi, S. A. (1976). Basics of Alminhaj. Najaf.

Makram, M. (1410). Lissan Al-Arab. Beirut.

Maraghaee, M. (1425). Alghawaed Alfeqhiah. Qom, Islamic Press.

Maraghaee, M. (2009). Alanavin. A. Zera't, Trans. Jangal Publications

Maraghaee, M. (2010). Alanavin.

Mohaghegh Damad, S. M. (2004). The rules of jurisprudence. Tehran University Press.

Mohaghegh Damad, S. M. (2006). The rules of jurisprudence. Tehran: Publication Center of Islamic Sciences.

Mohammadi, A. (1993). The rules of jurisprudence. Tehran: Yalda Publications.

Mostafavi, M. K. (1417). Alghawaed. Tehran: Institute of Islamic Press.

Mousavi Boroujerdi, S. M. (1993). Doctor criminal and civil liability. Journal of Law and Justice, (9).

Musawi Khomeini, S. R. (1425). Tahrir ul-Vassileh. Qom.

Najafi, M. H. (n. d.). Jawahir Al-Kalam. Beirut.

Noorbaha, R. (2009). The general criminal law. Ganje Danesh.

Qafy, H., \& Shariati, S. (2010). Applied rules of jurisprudence. SAMT Publications.

Qasem Zadeh, S. M. (2008). Obligations and civil liability. Mizan Publications.

Radan Jebelli, A. (1993). The impact of damage on the rights of the injured in Iran and British law. Master's thesis of Private Law, Faculty of Law, University of Shahid Beheshti.

Rastkar, S. (1986). Causal relationship between lack of commitment and loss. Master's thesis of Private Law, Faculty of Law and Political Sciences, Tehran University.

Safaei, S. H. (2004). The general rules of contract. Mizan Publications.

Safaei, S. H. (2006). The Civil Rights Foundation. Mizan Publications.

Sanglaji, M. (1973). Blocking reasons in law and jurisprudence. Tehran: Almjls Publications.

Sani, S. (2010). Alrozah Albahiyah. Islamic Thought Press.

Shafaei, M. (1973). Collection of rules of jurisprudence. Tehran: Naghshe Jahan Publications. 
Shahabi, M. (1962). The summary of statements and lessons. Farid Publications.

Shahidain. (n. d.). Alrozah Albahiyah Fi Allmh as Aldmshqyh.

Shirazi, R. (2009). The dynamism of Islamic jurisprudence. Forouzesh Publications.

Sobhi, M. (n. d.). Alnazarat Alamh Llmojibat va Aloqoud. Jamal al-Din Jamali Trans. Tehran. Aban Publications.

Tabatabai, M. H. (2000). Tafsir almizan.

Tajmiri, A. T. (1996). Civil Rights. Afrineh Cultural Institute.

Tusi, A. J. (n. d.). Almabsouvt. Tehran: Mortazavi.

Weir, T. (2006). An Introduction to tort law (2th ed.). Oxford University press Inc, New York.

William L, Prosser. (1964). law of tort (3th ed.). west publishing co.

Winfield, H. (1950). law of tort (15th ed.). London, Sweet \& Maxwell co.

\section{Copyrights}

Copyright for this article is retained by the author(s), with first publication rights granted to the journal.

This is an open-access article distributed under the terms and conditions of the Creative Commons Attribution license (http://creativecommons.org/licenses/by/3.0/). 